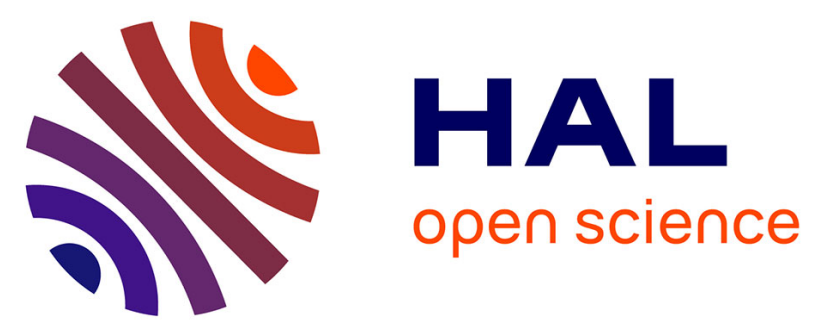

\title{
Accounting Professor Competencies: Identification of Educational Elements in the Education Process of Accounting Professors in Distance Education
}

\author{
Maria Ivanice Vendruscolo, Patricia Alejandra Behar
}

\section{- To cite this version:}

Maria Ivanice Vendruscolo, Patricia Alejandra Behar. Accounting Professor Competencies: Identification of Educational Elements in the Education Process of Accounting Professors in Distance Education. IFIP Conference on Information Technology in Educational Management (ITEM) and IFIP Conference on Key Competencies for Educating ICT Professionals (KCICTP), Jul 2014, Potsdam, Germany. pp.94-105, 10.1007/978-3-662-45770-2_10 . hal-01342689

\author{
HAL Id: hal-01342689 \\ https://hal.inria.fr/hal-01342689
}

Submitted on 6 Jul 2016

HAL is a multi-disciplinary open access archive for the deposit and dissemination of scientific research documents, whether they are published or not. The documents may come from teaching and research institutions in France or abroad, or from public or private research centers.
L'archive ouverte pluridisciplinaire HAL, est destinée au dépôt et à la diffusion de documents scientifiques de niveau recherche, publiés ou non, émanant des établissements d'enseignement et de recherche français ou étrangers, des laboratoires publics ou privés. 


\title{
Accounting Professor Competencies: Identification of Educational Elements in the Education Process of Accounting Professors in Distance Education
}

\author{
Maria Ivanice Vendruscolo and Patricia Alejandra Behar \\ Universidade Federal do Rio Grande do Sul (UFRGS), Brazil \\ maria.ivanice@ufrgs.br, patricia.behar@ufrgs.br
}

\begin{abstract}
The aim of this paper is to investigate the elements of teaching skills for professors of undergraduate courses in Accounting Sciences. The professor competencies were studied in order to identify those competencies applicable to the Accounting field. Studies about Accounting Professor training are recent and are tangent to the teacher competencies. They are not dedicated to map them and identify their elements, nor even addressed how to develop them. Hence, it is important to reflect on what skills are necessary for this professor. This is the intention in the continuation of this study in depth.
\end{abstract}

Keywords: Teaching Skills. Professors Competencies. Distance Education. Accounting Sciences.

\section{Introduction}

In the current globalized and evolving scenario, Accounting goes through a time of transition that promotes expansions in the functions of accountants, and, consequently, in their academic progress $[1,2,3,4]$. Similarly to what happens in other areas of knowledge, Accounting suffers the impacts of social, economic, scientific and technological factors and advances, resulting in changes in the practices and methodologies for calculating asset at a global level $[5,6,7,8]$.

Therefore, educational models are also impacted and evolve to include new elements brought by these advances in a significant way when compared to the education from the last century [9]. The professor's role in the training of future professionals acquires a scope that includes theoretical knowledge, pedagogy and professional experience. Thus, the practice of teaching in Accounting is complex [10], due to the relationship between theory and practice, as well as the constant changes brought by the scientific, social, economic and technological developments that have impact on the academic community and to the multiplicity of functions to be performed by the accountant.

The development and inclusion of information and communication technologies (ICT) in Education propel changes in pedagogical models in both types of education. Educational organizations have been making efforts to promote distance education and the incorporation of ICT in traditional didactic teaching methods [11], a worldwide tendency in terms of classroom and distance education $[12,13]$. 
Based on this reality, those involved with the education system, especially professors, need to follow and introduce them in their teaching practices. Consequently, professors are challenged to understand the new dynamics of transformative teaching and learning [14], how to develop skills for the practice of teaching in these circumstances, especially in higher education.

Discussing professor education contributes to the mediation between the new basis of social reality and the demands of skilled professionals to work in organizations in order to respond to evolving challenges of the world of work [15].

Strico Sensu programs are highly targeted to the technical and scientific training, emphasizing content and development research activities, to the detriment of the educational, social and political education of professors [16]. Studies have revealed that the training of professors of Accounting Sciences in Brazil does not contemplate the approach of cognitive theories and the development of professor competencies $[17,18,19,16,20,21,10]$.

Hence it is necessary to reflect on which competencies professors of undergraduate courses in Accounting Sciences are required. What are their elements? What are their specificities for higher education in Accounting? Pedagogical models that are relevant to distance education?

The objective of this bibliography research with qualitative strategy is to investigate the elements (knowledge, skills and attitudes) of competencies of professors of undergraduate courses in Accounting Sciences. The result of this study will support continuing research in order to map the professor competencies in Accounting and to identify mechanisms to develop them through the modality of distance education.

\section{Investigating the Teaching Skills}

In this section, we investigate the teaching skills in view of different researchers over time, to identify the specificities of their elements (knowledge, skills and attitudes) applicable to the teaching profession in Accounting.

The professor, just like any other professional, has to frame his/her training in two major stages [22]: "(1) preparing to enter the profession, commonly referred to as 'initial training'; and(2) continuing this initial training, updating it, reinforcing it by redirecting or even converting it to - a 'lifelong education' ".

It seems imperative that the development of teaching skills in professor education is an indispensable condition to the curricular competence approach [22].

The term "professor competence" is used in the sense of ability to act with wisdom and awareness of the consequences of his/her attitude. All competence involves at the same time, knowledge, how to do things, values and responsibilities for the results of what has been done [23]. "Competence also means theory and practice to do something, knowledge of the situation - which is required for any worker (and also for the professor)" [24].

Competencies are defined as "a set of interdependent and necessary knowledge, skills and attitudes in order to achieve certain purposes" [25]. Knowledge is considered as the mastery of the knowledge area and pedagogical-didactic aspects. 
Skills comprise interpersonal relationship, teamwork, creativity, systemic vision, communication, leadership and planning. Attitude refers to commitment, ethics, proactivity, empathy and flexibility [25].

Professors' skills to be developed in their training are intellectual, technical (mastering specific content), educational and political competences [26].

In the context of teaching and learning, competence is defined as knowing how to mobilize resources, expertise, know-how, tools and attitudes to effectively deal with complicated and unexpected situations [27]. The 10 core competencies necessary for teaching are listed below: organize and direct learning situations; manage the progression of learning; develop and evolve the devices of differentiation; engage students in their learning and in their work; work in teams; participate in school administration; inform and involve parents; use new technologies; meet the duties and the ethical dilemmas of the profession; and manage their own training.

Observing the three constituent elements of teaching skills, the key competences for the teaching and research investigated with professors [28] are showed on Table 1.

Table 1: Competencies for teaching and research

\begin{tabular}{lll}
\hline \multicolumn{1}{c}{ Knowledge } & \multicolumn{1}{c}{ Skills } & \multicolumn{1}{c}{ Attitudes } \\
\hline 1. Master knowledge area & \multicolumn{1}{c}{ 1. Interpersonal relationship } & \multicolumn{1}{c}{ 1. Commitment } \\
2. Didactic-pedagogic & 2. Teamwork & 2. Ethics \\
3. Scientific methodology & 3. Creativity & 3. Proactivity \\
& 4. Systemic view & 4. Empathy \\
& 5. Communication & 5. Flexibility \\
& 6. Leadership & \\
& 7. Planning & \\
\hline
\end{tabular}

These competencies constitute the minimum required for quality teaching [29]: communication skills, organizational skills, pedagogical leadership competencies, scientific competencies and competencies of assessment and control.

When addressing the teaching theme, some authors bring the term "knowledges", which is not a synonym for knowledge. The term "knowledges" is not a substance or content enclosed in itself, manifested through complex relationships between professors and their students." [30]. The sources of professor's "knowledge" are [30]: knowledge of the vocational training of Educational Sciences regarding initial and continuing professor training; disciplinary knowledges related to various fields of knowledge of the area; curricular knowledges related to programs (objectives, contents, methods); experimental knowledges developed in the daily work of professors.

Professors must have the ability to analyze complex situations; know how to reflectively decide the best strategies; know how to choose from a wide variety of skills and techniques, learn to critically analyze their actions and results, and know how to learn on a continuous basis throughout their career [31].

Main professor competencies were assigned to the university professor [32]: know how to communicate, in order to facilitate student learning, know how to learn, in order to continually renew their knowledge area in an interdisciplinary way; know how to commit and be closer to the difficulties faced by students, and learn how to take responsibility. 
Five characteristics identify professors' work in contemporary societies: knowledge, professional culture, pedagogical tact, teamwork and social commitment [33]: knowledge: the professor's work involves the construction of teaching practices that lead students to learning; the professional culture: the record of practice, reflection on the work and the evaluation exercise are central to the improvement and innovation; it is to understand the meanings of the school, be part of a profession, learn from their more experienced colleagues; pedagogical tact: relationship and communication ability without which the act of teaching is not fulfilled; teamwork: the new modes of professor professionalism imply the strengthening of collective and collaborative dimensions, teamwork, joint intervention in school educational programs; and social commitment: convergence towards the principles, values, social inclusion, cultural diversity.

Analyzing the different approaches of the authors referred to, a consensus about the skills of the university professor could not be identified. However, it is observed, in general, the presence of the three constituent elements of competencies: know (knowledge element), know how to do (skill element) and know how to be (Attitude element).

\section{Identifying Elements of Accounting Teaching Competences}

According to the Accounting Education Change Commission (AECC) five characteristics are identified in relation to effective teaching [34]:

- curriculum planning and course development : the professor should set appropriate goals, develop a useful structure for conducting courses and programs; conceptualize, organize and properly sequence the topics of the material; integrate the course with other courses, disciplines and related research, and be innovative and conducive to adapt to change;

- use of well-designed materials: it is essential, because they increase the skills of presentation, satisfy course objectives, are consistent with current developments and new technologies in the field of action, create a base upon which continued learning can be built, challenging the students to think, and giving them the tools to solve problems;

- Presentation Skills: stimulate students' interest and their active participation in the learning process, respond to developments in the classroom as they occur, convey mastery of the material, get objectivity on display, instilling professionalism, and engaging students in different learning styles;

- Well-chosen teaching methods and assessment devices: effective teaching methods, for example, experiments, cases, small group activities, vary with the circumstances (class size, the nature of the subject, skill or qualification that is being developed), assessment instruments (exams, projects, papers, presentations, etc.) must be suitable for both goals and the progress of the course, and must have an educational component, which is setting in the student's mind what is most important to learn, to think from a problem, identify weaknesses to be corrected and strengthen the required skills; and 
- guidance and counselling: an effective professor guides and advises students as to the appropriate level of study and research, i.e., a freshman student in exploring potential career, a student in the last year to find employment or a student in his doctoral thesis.

A survey with 73 recent graduates of $\mathrm{PhD}$ accounting programs in the United States in order to assess the needs of individual development in relation to effective teaching was conducted, taking into account five characteristics identified by AECC. The results of the study showed evidence of accounting professor development based on the recommendations of the AECC. However, despite the fact that respondents agree with the importance of the characteristics (especially curriculum development and presentation skills), they observed that they received little training and that they developed them primarily by self-training [34].

Seeking to characterize the identity of the professional accounting professor, some attributes were identified [18] as follows: the mastering of specific knowledge of their area of expertise in their appropriate initial and continuing education to relativize the knowledge produced by the society, becoming a subject capable of transforming social reality; professors' work that emphasizes the articulation of financial content with other areas of knowledge, surpassing the mere conception of know-how; professionalization that holds direct implications to the formation of professional accountants with a critical profile to the new context; the inclusion of working conditions in the forces in favor of valuing a wage policy and establishing a link in the initial and continuing education career; and understanding of the teachingresearch-extension as inseparable aspects of their work.

Three elements are present in the action of accountant professors [18] as follows: (i) organize teaching and learning situations suiting objectives, content and teaching methodologies with the course design, contributing to the quality of education as well as be aware of how to incorporate new technologies to the teaching work; (ii) coordinate research and participate in research groups to produce theoretical and practical knowledge; and (iii) master content and methodologies in order to convert scientific knowledge into curricular knowledge, considering their material conditions and their students.

However, for the teaching profession in Accounting, apart from specific knowledge, others are necessary to the professor: specialized training in the field, general education, didactic teaching, structure and functioning of higher education, education planning, and psychology of learning, teaching and assessment methods and techniques [19]. "For this purpose, it is not enough to know the specific content, professors must be able to know how learning occurs at each stage of human development, the ways of organizing the learning process and the methodological procedures for each content" [35].

This approach is grounded on the epistemological conceptions that professors have to respect the knowledge that underlies these pedagogical act, i.e., expresses a paradigm of educational thought on the understanding that people have of knowledge that empowers professors in pedagogical practices [30].

A study of competencies for the practice of teaching conducted with 267 professors in classroom courses in Northeast Brazil, assumes as its theoretical basis the responsibilities arising from the research [28]. Additionally, two competencies were 
included in the survey: Commitment and Flexibility [(36]. The measurable attributes are shown in Table $2[36,28]$.

Table 2: Skills and researched measurable attributes

\begin{tabular}{|c|c|}
\hline Competencies & Measurable attributes \\
\hline $\begin{array}{l}\text { Mastering the } \\
\text { knowledge area }\end{array}$ & $\begin{array}{l}\text { Have considerable knowledge of the subjects he/she teaches. Conduct } \\
\text { research in areas related to the subjects taught }\end{array}$ \\
\hline $\begin{array}{l}\text { Didactic- } \\
\text { pedagogic }\end{array}$ & $\begin{array}{l}\text { Possess fundamental knowledge of teaching and learning concepts. } \\
\text { Attend educational didactic courses }\end{array}$ \\
\hline $\begin{array}{l}\text { Interpersonal } \\
\text { Relationship }\end{array}$ & $\begin{array}{l}\text { Establish harmonious and healthy relationship with students. Manage to } \\
\text { balance the conflicts that may arise in relation to the students }\end{array}$ \\
\hline Teamwork & $\begin{array}{l}\text { Cooperate and get cooperation of colleagues in teaching activities with } \\
\text { common goals }\end{array}$ \\
\hline Creativity & $\begin{array}{l}\text { Create innovative solutions in educational activities under their } \\
\text { responsibility. }\end{array}$ \\
\hline Systemic view & $\begin{array}{l}\text { Realize the integration and interdependence between the subject and } \\
\text { other subjects taught in an undergraduate course }\end{array}$ \\
\hline Reflection & $\begin{array}{l}\text { Reflect with students on the relationship between what they are learning } \\
\text { and global aspects of science and / or society as a whole }\end{array}$ \\
\hline Communication & $\begin{array}{l}\text { Listen, process, and understand the different needs of students and } \\
\text { provide appropriate feedback }\end{array}$ \\
\hline Leadership & $\begin{array}{l}\text { Encourage students to achieve personal goals in their learning process. } \\
\text { Influence students regarding their personal responsibilities in their } \\
\text { learning process }\end{array}$ \\
\hline Planning & $\begin{array}{l}\text { Know how to elaborate syllabus and courses programs of undergraduate } \\
\text { disciplines. Know how to prepare teaching materials to support course } \\
\text { activities. Arrange the logical sequence of activities for each lesson } \\
\text { taught. }\end{array}$ \\
\hline Commitment & $\begin{array}{l}\text { Commitment to obtaining positive results in educational activities under } \\
\text { their responsibility. Be available to provide out-of-class support to } \\
\text { students. }\end{array}$ \\
\hline Ethics & $\begin{array}{l}\text { Demonstrate respect for students; use a single evaluation criterion for all } \\
\text { students. }\end{array}$ \\
\hline Proactivity & $\begin{array}{l}\text { Have personal initiative to practice concrete actions that contribute to the } \\
\text { improvement of the educational process in general. }\end{array}$ \\
\hline Empathy & $\begin{array}{l}\text { Promote trust and harmony with the students leading to a greater degree } \\
\text { of openness to accept their advice and suggestions. }\end{array}$ \\
\hline Flexibility & $\begin{array}{l}\text { Adapt to new situations when necessary, face new challenges in the } \\
\text { educational processes in which you operate. Be willing to revise the } \\
\text { teaching process based on results of assessments made. Making self- } \\
\text { assessment of your work as a professor. }\end{array}$ \\
\hline
\end{tabular}

Statistical analysis showed that all competencies achieved an average above 7.9 in the perception of respondents, on a scale of 0 to 10 at the level of perceived importance. The best results were Ethics (9.2), Commitment, Flexibility, Interpersonal Relationship, Planning and Leadership. Didactic-pedagogic competence was in the final position, with an average of 7.9 [36].

Additionally, some important factors were tested for a better professor performance. They are [36]: 1. Title (professors who have stricto sensu courses versus those who do not). 2. Employment at the institution of higher education (professors 
who have more hours versus teaching fewer hours). 3. Time experience as a professional in the accounting area (professors who have longer experience as professionals in the accounting area versus professors with less experience). 4. Research and extension (professors who have publications or participate in research projects and extension versus professors who did not participate in these projects or do not have publications).

The results of the statistical tests showed that the title factor showed a statistically significant difference $(95 \%)$ of $\mathrm{PhD}$ professors and $\mathrm{PhD}$ students in the didactic and pedagogical competence, Commitment and Planning in relation to other professors in the sample. The length of professional experience also proved influential in determining the most competent professors [36].

In another survey of 95 American professors who were certified Accounting $\mathrm{PhD}$, the following skills for teaching accounting were investigated [21]: skills to teach accounting topics; skills to teach various subjects and teaching styles; research skills and publication; the ability to advise students and participate in curriculum development; skills related to the transmission of critical thinking, communication, writing, teamwork, and other non-technical accounting skills; and participation in Professional Continuing Education.

The calculated results indicate that teaching experience was the most influential item in the acquisition of valued skills, after the ability to conduct research in which the preparation made by the doctoral program was the item most influential [21].

Another $\mathrm{PhD}$ research, with the aim to investigate the association between professor qualifications and student performance of undergraduate Accounting students [10] considered the qualification in three areas of professor training: Academic qualification, Professional qualification and Pedagogical qualification. It investigated the literature, the factors that constitute the teaching of these skills Accounting and validated by means of the Delphi Technique [10]. Components factors calculated by the author are described: i) Academic qualification: Title: PhD (preparation for research), master, specialist, acting as referee or reviewer of scientific journals, work in HEIs with exclusive dedication, owning publications in scientific journals, participation in associations or bodies of research. Thus, it was found that the academic qualification relates to professor preparation for conducting research on the topics taught; ii) Professional qualification: Acting in the accounting profession; as a consultant, advisor or referee; participation in professional associations or regulatory agencies; development of applied research involving academic environment and the community, participation in university extension projects with community involvement; and iii) Pedagogical qualification: Offering preparation programs for professors, support professor participation in research projects and scientific events; support professor participation in stricto sensu courses from other HEIs; promotion of scientific events that include education / teaching; having strict professor training course stricto sensu, lato sensu and extension; research projects related to teaching, and teaching experience.

A survey with 20 professors and 209 students of Accountancy [14] in the Philippines was carried out. The study aimed to evaluate the skills and teaching skills instruction, management, human resources, technical, conceptual and personal and social characteristics. The skills and abilities assessed [14] are described in Table 3. 
Table 3. Assessment of Competencies of Accounting

\begin{tabular}{ll}
\hline Competence & Assessment of Competencies of Accounting \\
\hline Instructional & States clearly the objectives of the subject / lesson; Presents concepts clearly; \\
Skills & Has a thorough mastery of the subject matter; Updated with latest \\
& development in the field and can relate subjects to other fields and life \\
& situations; Welcomes questions pertinent to the subject matter; Stimulates \\
& students' interest in the subject; Encourages students to have a more critical \\
& thinking about accounting problems; Encourages creative thinking in solving \\
& accounting problems; Gives tests within the subject matter already discussed; \\
& Has a good command of the language instruction; Makes use of various \\
& teaching aids; Presents lessons using the appropriate teaching strategies and \\
& methods like recitation, lecture, demonstration, etc. to ensure the students \\
understanding; and Has good diction, clear and modulated voice.
\end{tabular}

The results showed that professors are efficient in the use of teaching skills and management skills. They also possessed human skills and techniques required to ensure the formation of competitive market students [14].

An exploratory study of professors in the areas of Business and Accounting of higher education institution was conducted in Mexico. The research had the purpose of identifying the skills in information technology, and analyze the factors that determine the use of these technologies, for these professors. The results revealed four ICT skills [37]: (i) use of text files and tools, (ii) capabilities in the operating system, (iii) use of database and multimedia; and (iv) preparation of presentations and Internet 
use. The factors identified by professors in the sample were: Positive view of teaching using ICT, teaching and training in the use of such technologies and availability of infrastructure [37].

Other studies have been conducted taking into consideration students' perception about Accounting professor qualifications and their relevant characteristics. The main results are shown in Table 4.

Table 4. Main characteristics of the professor by the student perception

\begin{tabular}{|c|c|}
\hline Authors & Results \\
\hline$[38]$ & $\begin{array}{l}\text { students surveyed prefer professors who have a balance between the emotional } \\
\text { and intellectual attributes, while the studies of Lowman highlight professors with } \\
\text { intellectual stimulation; the reasons for the good professor are chosen based on } \\
\text { the quality of the professor's pedagogic practice and mastery of content; } \\
\text { educational and organizational attributes in the intellectual stimulation dimension } \\
\text { and attentiveness, interest and helpfulness attributes in the interpersonal } \\
\text { dimension; regarding pedagogical practice, professors are well respected, but } \\
\text { rarely negatively evaluated, including the ability to challenge students, the forms } \\
\text { of evaluation and enthusiasm to teach. }\end{array}$ \\
\hline$[39]$ & $\begin{array}{l}\text { students considered didactics, followed by theoretical knowledge, as the two } \\
\text { most relevant skills out of five skills studied: didactics, relationship, level of } \\
\text { demand, theoretical knowledge and market experience. }\end{array}$ \\
\hline$[40]$ & $\begin{array}{l}\text { students value the mastery of knowledge, didactics / methodology and teaching } \\
\text { strategies, attitudes and personal attitudes of professors, but also value teaching } \\
\text { that corresponds to the satisfaction of their interests and immediate needs. }\end{array}$ \\
\hline [41] & content mastery as a key competence for Accounting professors. \\
\hline$[42]$ & $\begin{array}{l}\text { content mastery, clarity, motivation, readiness to answer questions and be } \\
\text { communicative. }\end{array}$ \\
\hline$[43]$ & $\begin{array}{l}\text { factors for development of teaching skills were: A PhD: Didactic-pedagogical } \\
\text { factors, planning and commitment; Influence of teaching experience in terms of } \\
\text { time. }\end{array}$ \\
\hline$[44]$ & $\begin{array}{l}\text { the practice disciplines were perceived throughout the course as the most } \\
\text { significant learning, being didactic or teaching methodology, attitudes and } \\
\text { personal qualities of the professor the main reasons for the choice of teaching } \\
\text { reference. }\end{array}$ \\
\hline [45 & $\begin{array}{l}\text { students chose mastery of knowledge, teaching and market experience as the } \\
\text { most relevant skills to the practice of teaching in the Accounting course. }\end{array}$ \\
\hline
\end{tabular}

\section{Final Considerations}

Analyzing the different approaches of the authors referred to, a consensus could not be identified about the teaching skills of professors. However, it is observed, in general, the presence of the three constituent elements of competencies: knowledge, skills and attitudes.

Studies about Accounting Professor training are recent and tangent to the professor competencies. They are not dedicated to map them and identify their elements, nor even addressed how to develop them. Hence, it is important to reflect on what skills 
are necessary for this professor. This is the intention in the continuation of this study in depth.

The development of teaching skills in accounting requires additional studies, particularly in relation to distance education, which is still in progress.

On the other hand, universities worldwide have thought of new institutional arrangements, with flexible schedules and more sophisticated pedagogical architectures to meet the demands of a globalized and competitive market. This alternative also meets the increasingly empowered emerging challenges of the profession, including teaching scenario in the Brazilian accounting with a lack of professionals.

Based on the questions presented, it is understood that Accounting professors need to monitor innovative changes introduced in education and incorporate them or adapt them to their pedagogical practice as well as develop new teaching skills to work in this scenario.

\section{References}

1. Cardoso, R. L.: Accountant Skills: an empirical study. School of Economics, Business and Accounting, São Paulo's University (2006)

2. Passos, I. C.: Critical Reasoning of Undergraduate Students in Accounting: application of instructional model Richard Paul. School of Economics, Business and Accounting, São Paulo's University (2011)

3. Miller, W. F., Becker, D. A.: Why Are Accounting Professors Hesitant to Implement IFRS. The CPA Journal. 80(8), 63-67 (2010)

4. Ott, E., Cunha, J. V. A da, Cornacchione Junior, E. B, De Luca, M. M. M.: Relevance of knowledge, skills and instructional methods from the perspective of students and professionals in the accounting area: international comparative study. Revista Contabilidade Finanças [online]. 22(57), 338-356 (2011)

5. Theóphilo, C. R.: Research in Accounting in Brazil: a critical-epistemological analysis. School of Economics, Business and Accounting, São Paulo's University (2004)

6. Cornachione Junior, E. B. Technology for education and courses in accounting: virtual collaborative models. School of Economics, Business and Accounting, São Paulo's University (2004)

7. Sá, A. L. de: Fundamentos da contabilidade geral. Juruá, Curitiba, PR (2005)

8. Iudícibus, S. de: Some essay about deep roots of accounting in supporting fundamental principles. Revista de Contabilidade e Organizações - RCO. 1(1), 815 (2007)

9. Avendaño-Castro, W. R.: Un Modelo pedagógico para la educación ambiental desde la perspectiva de la modificabilidad estructural cognitiva. Revista Luna Azul. 36(2),110-133 (2013)

10. Miranda, G. J.: Relationship between teacher qualifications and student performance in undergraduate accounting in Brazil. School of Economics, Business and Accounting, São Paulo's University (2011) 
11. Behar, P. A.: Modelos pedagógicos em educação a distância. Artmed, Porto Alegre, RS (2009)

12. Moore, M. G., Kearsley, G.: Educação a distância: uma visão integrada. Translation by Roberto Galman. 2nd reprint. 1st. Edition. Cengage Learning, São Paulo, SP (2008)

13. Peters, O.: A educação a distância em transição: tendências e desafios. Translation by Leila Ferreira de Souza Mendes. Editora Unisinos, São Leopoldo, RS (2009)

14. Del Mundo, G. V., Refozar, R. F G.: The accounting teachers of Batangas: their profiles competencies and problems. International Scientific Research Journal. $\mathrm{V}(1), 131-166$ (2013)

15. Kraemer, M. E. P.: Reflections on the teaching of accounting. Revista Brasileira de Contabilidade. 153(2), 65-80 (2005)

16. Andere, M. A., ARAÚJO, A. M. P.: Aspects of teacher training higher education in accounting sciences: an analysis of graduate programs. Rev. contab. finanç.[online]. 19(48), 91-102 (2008)

17. Nossa, V.: Formation of the faculty training of graduate courses in accounting in Brazil: a critical analysis. 1999. Cadernos de Estudos FIPECAFI. 21(2), 1-20 (1999)

18. Laffin, M.: Teacher of the accountant: the trajectory of teaching in higher education accounting. Imprensa Universitária, Florianópolis (2005)

19. Gil, A. C.: Didática do Ensino Superior. Atlas, São Paulo, SP (2006)

20. Slomski, V. G.: Know that underlie pedagogical practice professor of accounting. In: VIII Congresso USP de Controladoria e Contabilidade. Anais... São Paulo: July (2008)

21. Marshall, P. D., Dombrowski, R., Garner, M., SMITH, K.: The accounting education gap. The CPA Journal. 80(6), 6-10 (2010)

22. Gaspar, M. I.: Competencies in question: contribution to the training of teachers. Discursos. Series: Perspectives on education, Lisboa, PT (2004)

23. Braslavsky, C.: Rules, guidelines and criteria for the design of teacher training programs. Revista Iberoamericana de Educación. Buenos Aires. 19(1), 13-50 (1999)

24. Pimenta, S. G, Anastasiou, L. G. C.: Docência no ensino superior. 3th Edition. Cortez, São Paulo, SP (2008)

25. Durand, T.: Forms of incompetence. In: International Conference On Competence Based Management. IV, 1998. Oslo. Anais ... Oslo: Norwegian School Management (1998)

26. Zabala, A.: A prática educativa: como ensinar. Artmed, Porto Alegre, RS (1998)

27. Perrenoud, P.: Dez novas competências para ensinar. Artmed, Porto Alegre, RS (2000)

28. Pereira, M. A. C.: Competencies for teaching and research: a survey of teachers of chemical engineering. Polytechnic School, São Paulo's University (2007)

29. Bozu, Z., Canto, P.: University teaching in the knowledge society: teaching skills. Revista de Formación e Innovación Educativa Universitaria, 2(2), 87-97 (2009)

30. Tardif, M.: Saberes docentes e formação profissional. 9th. Edition. Vozes, Petrópolis, RJ (2008) 
31. Paquay, L. et al.: Formando professores profissionais: quais estratégias? Quais competências? Translation by Fátima Murad and Eunice Gruman. 2nd Edition. Artmed, Porto Alegre, RS (2001)

32. Karawejczyk, T. C., Estivalete, V.: University professor: the meaning of their work and develop new skills in a changing world. In: Encontro Anual da ANPAD, 27. Anais... Atibaia: ANPAD (2003)

33. Nóvoa, A.: Professores: imagens do futuro presente. EDUCA Instituto de Educação da Universidade de Lisboa, Lisboa, PT (2009)

34. Swain, M. R., Stout, D. E.: Survey evidence of teacher development based on AECC Recommendations. Journal of Accounting Education. Edition. 18(2), 99113 (2000)

35. Kuenzer, A. Z.: Training policies: the establishment of the identity of the teacher Sobrante. Revista Educação \& Sociedade. 68(Special Edition), 163-183 (1999)

36. Vasconcelos, A. F de.: Teachers in accounting: a study on skills for the practice of teaching in classroom courses in Northeast Brazil. Multi-institutional and Inter-Regional Postgraduate Programme in Accounting, Federal University of Paraiba and Federal University of Rio Grande do Norte (2009)

37. Pedraza, N., Farias, G., Lavin, J., Torres, A.: The ICT teaching skills in the areas of business and accounting: an exploratory study in higher education. Perfiles educativos [online]. 35(139), 8-24 (2013)

38. Celerino, S., Pereira, W. F. C.: Attributes and pedagogical practice of accounting professor who has success in the university environment: a view of academics. Revista Brasileira de Contabilidade. 37(170), 65-77 (2008)

39. Gradvohl, R. F., Lopes, F. F. P., Costa, F. J da.: The profile of good accounting professor: an analysis from the perspective of students for Graduation. In: Congresso USP Controladoria e Contabilidade, 9., 2009, São Paulo. Anais... São Paulo (2009)

40. Volpato, G.: Brands of professionals to become teachers-reference. Revista Brasileira de Estudos Pedagógicos. 90(225), 333-351(2009)

41. Gomes, M. E. M. et al.: Attributes and pedagogical practices of accounting professor who has succeeded in the classroom: a study of student perceptions in public HEIs. In: Encontro de Pesquisa Em Administração e Contabilidade, 2., 2009. Anais... Curitiba (2009)

42. Catapan, A., Colauto, R. D., Sillas E. P.: Perception of students about the exemplary teachers in public accounting and private HEIs. RIC - Revista de Informação Contábil. 6(2), 63-82 (2012)

43. Vasconcelos, A. F. de, Calvalcante, P. R. N., Monte, P. A.: Fatores que influenciam as competências em docentes de Ciências Contábeis. VEREDAS FAVIP - Revista Eletrônica de Ciências. 5(1), 86-101 (2012)

44. Miranda, G. J., Casa Nova, S. P. de C., Cornacchione Junior, E. B.: The knowledge of teachers-reference in accounting education Rev. Contab. Finanç. [online]. 23(59), 142-153 (2012)

45. Rezende, M. G., Leal, E. A.: Competencies required of teachers of accounting course in perception of students. Sociedade, Contabilidade e Gestão. 8(2), 145160 (2013). 